\title{
ROZWÓJ SZKOLNICTWA WYŻSZEGO W WOJEWÓDZTWIE LÓDZKIM
}

\author{
Development of university level education in the Lódź Voivodeship
}

\begin{abstract}
ANITA WOLANIUK ${ }^{*}$ (iD
Zarys treści. Autorka w swym artykule przedstawiła rys historyczny szkolnictwa wyższego w województwie łódzkim oraz jego rozwój, w tym zwłaszcza okresy gospodarki centralnie planowanej (1945-1989) i gospodarki wolnorynkowej (po 1990 roku). Poza liczbą szkół wyższych, w analizie tej uwzględniono liczbę studentów w uczelniach publicznych i niepublicznych województwa łódzkiego, ich absolwentów oraz nauczycieli akademickich. Przedstawiono także ośrodki zamiejscowe łódzkich uczelni, w tym także położone poza granicami województwa łódzkiego. Nie uwzględniono zaś szkół kościelnych ani wojskowych, dla których dane nie są dostępne w statystykach Głównego Urzędu Statystycznego i Wojewódzkiego Urzędu Statystycznego.

Słowa kluczowe: wyższe szkoły publiczne i niepubliczne, zamiejscowe ośrodki dydaktyczne, studenci, nauczyciele akademiccy

Abstract. The author has presented a historical outline of the development of university level education in the Lódź Voivodeship, especially during periods of centrally planned economy (1945-1989) and free market economy (since 1990). Numbers of higher education institutions (public and non-public), of students, of graduates and of academic teachers were analysed. Church and military schools were not considered, because data concerning them were not provided, neither by the Statistics Poland nor by the Łódź Voivodeship Statistical Office. The distribution of extraneous university branches (operating outside Łódź City and even outside of the Łódź Voivodeship) was also discussed.
\end{abstract}

Key words: state and private universities, extraneous university branches, students, academic teachers

\section{Wstęp}

Funkcja akademicka realizowana przez szkoły wyższe należy w przypadku województwa łódzkiego do młodszych jego funkcji metropolitalnych, co jest następstwem swoistego rozwoju historycznego tego obszaru. W odróżnieniu od dużych regionów geograficzno-historycznych Polski, jak np. Małopolska, Wielkopolska, Mazowsze, kształtowanych wraz z rozwojem państwa polskiego, rozwinął się później, jako typowy region gospodarczy. Województwo łódzkie powstało na pograniczu kilku dawnych ziem, na wododziale Odry i Wisły, w dorzeczu ważnych dopływów tych rzek: Warty, Pilicy i Bzury. Z dolin tych rzek rozpoczęła się ekspansja osadnictwa ku wnętrzu późniejszego województwa i jego stolicy - Łodzi. Dlatego też jedno z pierwszych i najważniejszych opracowań naukowych poświęconych województwu łódzkiemu autorstwa Jana Dylika nosi tytuł „Województwo ze stolicą bez antenatów" (Dylik 1971), a najstarsze ośrodki miejskie leżą $\mathrm{w}$ dolinach wymienionych rzek.

Na przykład w Łowiczu, wraz z powstaniem kapituły łowickiej i podniesieniem miejscowego kościoła NMP do rangi kolegiaty utworzono najstarszą na terenie obecnego województwa łódzkiego szkołę kolegiacką, uznawaną za najstarszą w Polsce filię Akademii Krakowskiej - obecnego UJ. Dzięki obecnym w mieście fundacjom zakonów dominikanów (1414 r.) i bernardynów (1468 r.) pojawiła się tam warstwa inteligencji dużo wcześniej, aniżeli w Łodzi. Sprzyjało to utworzeniu w Łowiczu w 1668 r. kolegium pijarskiego, a w 1700 r. - Seminarium Duchownego. Natomiast w Łodzi, Wyższe Seminarium Duchowne zostało erygowane 9 sierpnia 1921 r., zatem po przeszło dwustu latach i w dwa lata po utworzeniu województwa łódzkiego.

Oznacza to, że najstarsze szkoły, które aspirowały do rangi szkół wyższych miały charakter

\footnotetext{
* Uniwersytet Łódzki, Wydział Nauk Geograficznych, Instytut Geografii Miast i Turyzmu, ul. Kopcińskiego 31, 90-142 Łódź; e-mail: a.wolaniuk@gmail.com, ORCID: https://orcid.org/0000-0002-0563-6767
} 
katolicki i podlegały administracji Kościoła. Zdaniem łódzkich historyków, po utworzeniu w Lodzi szkoły parafialnej, do połowy XVIII w. dziewiętnastu łodzian studiowało w Akademii Krakowskiej, a trzech $\mathrm{z}$ nich pracowało $\mathrm{w}$ tamtejszych katedrach UJ (Baranowski, Kaczmarek 1952). Jednak dopiero rozwój przemysłowy Łodzi w XIX w. skłonił nieliczne wówczas elity intelektualne miasta do działań na rzecz utworzenia w Łodzi szkoły wyższej. Dążono do otwarcia wyższej uczelni technicznej, która miałaby kształcić kadry dla szybko rozwijającego się przemysłu. Mimo że po upadku powstania styczniowego i zamknięciu Instytutu Politechnicznego i Rolniczo-Leśnego w Puławach, Łódź została wybrana na siedzibę takiej uczelni, nie doszło do tego (Bandurka 1987). Władze carskie, obawiając się wzmocnienia pozycji łódzkich przemysłowców, blokowały utworzenie w Lodzi szkoły wyższej, a właściciele zakładów przemysłowych (głównie pochodzenia niemieckiego i żydowskiego) kształcili dzieci w Europie Zachodniej i nie byli zainteresowani założeniem takiej szkoły. Przed wizytą w Łodzi cara Mikołaja II, władze otrzymały zezwolenie na utworzenie politechniki, ale ostatecznie jej siedzibą została Warszawa ${ }^{1}$. Intensywny rozwój przemysłu sprzyjał rozwojowi demograficznemu miasta, które w drugiej połowie XIX w. było trzecim co do wielkości miastem $\mathrm{w}$ granicach obecnej Polski (po Warszawie i Wrocławiu) bez wyższej uczelni. W latach 80. XIX w. otwarto w Łodzi tylko tzw. wyższą szkołę rzemieślniczą, średnią szkołę włókienniczą, nazywaną powszechnie „Małą Politechniką" (Bandurka 1987). Dalsze starania łódzkich elit intelektualnych doprowadziły do powołania Dyrekcji Naukowej, niemniej jej starania także nie doprowadziły do powołania wyższej uczelni. Dopiero po odzyskaniu przez Polskę niepodległości i ustanowieniu z dniem 2 sierpnia 1919 r. przez Sejm Tymczasowy województwa łódzkiego, Łódź stała się siedzibą władz naukowo-oświatowych dla Okręgu Łódzkiego, co zaowocowało powołaniem w tym wielkim już mieście placówek oświatowych i naukowych, m.in. Inspektoratu Szkolnego Okręgu Łódzkiego, Seminarium Nauczycielskiego i Badawczego Zakładu Państwowego (Wolaniuk 1997).

\section{Próby tworzenia szkolnictwa wyższego w okresie międzywojennym}

Już w 1921 roku po uzyskaniu przez Łódź statusu miasta wojewódzkiego do sejmu złożono wniosek o utworzenie Politechniki Łódzkiej, sejm wniosek ten poparł, ale sprzeciw zgłosił Minister Skarbu, który niestety wyraził zgodę na powołanie Politechniki Warszawskiej (Przybylski 1995). Rok później, jeden ze znanych łódzkich przemysłowców - Oskar Kon, współwłaściciel Widzewskiej Manufaktury z okazji jubileuszu 25-lecia swojej funkcji dyrektorskiej przeznaczył $50 \mathrm{mln}$ marek na utworzenie politechniki w Łodzi, jednak jego starań nie zaakceptowały władze państwowe. $Z$ kolei w 1923 r. Kuratorium Okręgu Szkolnego Łódzkiego wystąpiło do rządu z propozycją utworzenia uniwersytetu państwowego, niestety i ta prośba spotkała się z odmową.

Wraz z rozwojem funkcji administracji szczebla wojewódzkiego w Łodzi zorganizowano władze oświatowe dla Okręgu Łódzkiego oraz Łódzkie Koło Towarzystwa Nauczycieli Szkół Średnich i Wyższych, które utworzyło w 1921 r. Instytut Nauczycielski (Baranowski 1977). Instytut ten cieszył się dużym zainteresowaniem, co potwierdza liczba jego słuchaczy - wynosząca prawie 2 tys. osób. Kadrę wykładowców Instytutu stanowili, poza nauczycielami łódzkich szkół średnich, przede wszystkim dojeżdżający do Łodzi profesorowie i docenci uniwersytetów z Warszawy, Krakowa i Poznania oraz z Wolnej Wszechnicy Polskiej i Państwowego Instytutu Nauczycielskiego (Jałmużna 1996). Ponieważ przyjeżdżali oni na zajęcia stosunkowo rzadko, nie zapewniało to ciągłości nauczania, ani nawiązywania więzi ze słuchaczami. W pierwszych latach funkcjonowania Instytutu wykładowcami byli wybitni naukowcy, więc kierownictwo liczyło na przekształcenie go w wyższą uczelnię. Jednak dojeżdżający profesorowie nie zamieszkali na stałe w Łodzi, ani nie wykształcili swoich następców, a trudności finansowe Instytutu Nauczycielskiego, namiastki wyższej uczelni, spowodowały, że działał tylko do $1928 \mathrm{r}$.

Jak już wspomniano wcześniej, w 1921 r. rozpoczęło w Lodzi działalność Wyższe Seminarium Duchowne, które w 1938 r. uzyskało status wyższej uczelni. Kolejną łódzką uczelnią była powołana w 1924 r. Wyższa Szkoła Nauk Społecznych i Ekonomicznych (WSNSiE), niestety działała ona tylko cztery lata, do czasu utworzenia w 1928 r. Oddziału

\footnotetext{
${ }^{1}$ W 1897 r. był to rosyjski Warszawski Instytut Politechniczny (Kwiatek, Lijewski 1998).
} 
Łódzkiego Warszawskiej Wolnej Wszechnicy Polskiej, za sprawą dr. Edmunda Jana Reymana, dyrektora Warszawskiej Szkoły Nauk Politycznych, autora znamiennych słów: „...półmilionowe miasto, metropolia naszego przemysłu i handlu, ośrodek życia gospodarczego, nie posiada własnej uczelni naprowadziło myśl moją w kierunku rozważań, których wynikiem było powzięcie postanowienia utworzenia w tym mieście uczelni..." (za Baranowskim 1993). W zamyśle E. J. Reymana WSNSiE miała funkcjonować na wzór Warszawskiej Szkoły Nauk Politycznych, czyli kształcić pracowników dla instytucji gospodarczych i administracji. Łączna liczba słuchaczy w latach 1924-1928 wyniosła około 400 osób. Uczelnia mieściła się w Gimnazjum Zgromadzenia Kupców przy ul. Narutowicza 88 (w obecnym gmachu Rektoratu UŁ). Była to pierwsza szkoła typu wyższego. Jako że władze miejskie prowadzily starania o utworzenie w Łodzi filii Warszawskiej Wolnej Wszechnicy Polskiej, w 1928 r. dr E. J. Reyman zrezygnował z pełnienia funkcji dyrektora WSNSiE, co skutkowało zamknięciem szkoły (Baranowski 1993).

Jesienią 1928 r. rozpoczął więc w Łodzi działalność Oddział Łódzki Warszawskiej Wolnej Wszechnicy Polskiej (OŁWWP). Była to pierwsza $\mathrm{w}$ województwie łódzkim uczelnia $\mathrm{z}$ uprawnieniami akademickimi, czyli prawem nadawania stopnia naukowego magistra. OŁWWP w pełni podlegał uczelni warszawskiej, wspólne były władze rektorskie i dziekańskie. Rektorem tej uczelni do wybuchu II wojny światowej był Teodor Vieweger. Od 1928 r. zajęcia prowadzono na trzech wydziałach: Humanistycznym, Prawa i Nauk Ekonomiczno-Społecznych oraz Pedagogicznym, a później także na czwartym Wydziale, Nauk Matematyczno-Przyrodniczych. Ponieważ Łódź nie dysponowała wtedy odpowiednią kadrą akademicką, na zajęcia przyjeżdżali profesorowie i docenci z uczelni warszawskiej, w ramach godzin nadobowiązkowych. W okresie międzywojennym na OŁWWP studiowało blisko 4,5 tys. osób, a w 1938 roku liczba studentów wynosiła 645 osób. O dużym zapotrzebowaniu ówczesnej Łodzi na wykształcone kadry świadczy fakt, że około $70 \%$ studentów pracowało zawodowo, przede wszystkim jako urzędnicy i nauczyciele (Baranowski 1993). Poza czteroletnim systemem kształcenia akademickiego, władze OŁWWP prowadziły kilka kursów o charakterze dokształcającym.

Łodzianie podjęli także próbę utworzenia Wyższej Szkoły Handlowej. Jej organizacją zajęło się specjalnie powołane w tym celu Kuratorium Wyższej Szkoły Handlowej. Stowarzyszenie to otrzymało od sfer rządowych w 1938 r. obietnicę utworzenia takiej szkoły, ale niestety do jej założenia także nie doszło. Również niepowodzeniem zakończyła się próba powołania w Łodzi Instytutu Prawa Administracyjnego i Wyższej Szkoły Lekarskiej (Kita, Pytlas 1996). Należy jeszcze tu wspomnieć o działalności Komitetu Wyższej Uczelni Lekarskiej i profesorze W. Tomaszewiczu, który usilnie zabiegał o powołanie Akademii Lekarskiej (Bandurka 1987). Komitet ten wspierały zarówno władze miejskie, jak i kościelne, wspierając go argumentami o łódzkim zapleczu szpitalnym przygotowanym do potrzeb klinicznych. Niemniej silna opozycja środowisk lekarskich (szczególnie z uniwersytetów krakowskiego i poznańskiego) udaremniła powołanie uczelni medycznej w Łodzi.

Jednakże działające w międzywojennej Łodzi trzy placówki: Instytut Nauczycielski, prywatna Wyższa Szkoła Nauk Społecznych i Oddział Łódzki Warszawskiej Wolnej Wszechnicy Polskiej dały podstawy do utworzenia pełnoprawnych wyższych uczelni.

\section{Zabiegi o powołanie wyższych uczelni w czasie II wojny światowej}

W czasie okupacji niemieckiej działała w Łodzi konspiracyjna komisja do spraw wyższego szkolnictwa, w której składzie byli m.in. Bolesław Wilanowski - profesor Uniwersytetu Wileńskiego, Tadeusz Pawlikowski - docent wydziału lekarskiego Uniwersytetu Poznańskiego i adwokat Henryk Kurnatowski. Przygotowała ona projekt wielowydziałowego uniwersytetu państwowego, lecz jej intensywne prace w latach 1942-43 przerwała seria aresztowań kilku członków.

Prace nad utworzeniem w Łodzi wyższej uczelni prowadzone były zarówno przez rząd londyński i jego delegaturę na kraj, jak i w środowiskach łódzkim i warszawskim. Projekt rozwoju w Łodzi szkolnictwa wyższego został m.in. przygotowany w 1944 r. na zlecenie rządu londyńskiego przez łódzkich działaczy kultury - Zygmunta Lorentza i Ludwika Waszkiewicza. Zakładał on utworzenie w Łodzi uczelni politechnicznej i odtworzenie Wolnej Wszechnicy Polskiej. O tę drugą zabiegał także przedwojenny jej rektor, prof. Teodor Vieweger, jednak grono profesorskie Wszechnicy dążyło do utworzenia w Łodzi nowego państwowego uniwersytetu. Podobny projekt powołania złożyło do rządu londyńskiego także grono młodych docentów Uniwersytetu Warszawskiego. Z kolei przedstawiciele łódzkiego środowiska naukowego przedłożyli rządowi w Londynie projekt utworzenia w Łodzi Akademii Włókienniczej, która zajęłaby 
się kształceniem kadr dla największego w Polsce ośrodka tego przemysłu.

Należy podkreślić, że gorącymi orędownikami utworzenia w Łodzi nowych uczelni byli dwaj adwersarze: prof. Vieveger i prof. Wilanowski. Ci dwaj naukowcy optujący za różnym modelami uczelni uczestniczyli m.in. w kilku konferencjach w lutym i marcu 1945 r., na których, niestety, nie doszli do zgody. Zaniepokojone władze miejskie wystąpiły do Ministerstwa Oświaty o przyspieszenie wydania dokumentów powołujących w Łodzi uniwersytet i politechnikę.

\section{Szkolnictwo wyższe w województwie lódzkim w okresie gospodarki centralnie planowanej (1945-1989)}

Tuż po wyzwoleniu podjęto na nowo prace nad powołaniem w Łodzi wyższych uczelni: uniwersytetu, politechniki, uczelni medycznej, rolniczej oraz filii Szkoły Głównej Handlowej z Warszawy. Starania te zostały uwieńczone dekretem z 24 maja 1945 r. powołującym Uniwersytet Łódzki i Politechnikę Łódzką, ogłoszonym w Dzienniku Ustaw Rzeczypospolitej Polskiej nr 21 (27 sierpnia 1945 r.). Rozporządzeniem Ministerstwa Oświaty (opublikowanym w Dzienniku Urzędowym nr 4, poz. 243) powołano do życia w ramach tego nowego Uniwersytetu trzy wydziały medyczne: lekarski, farmaceutyczny i stomatologiczny (Kiciński 1987). W 1945 r. odbyły się uroczyste inauguracje akademickie w 8 uczelniach: na Uniwersytecie i Politechnice oraz w Państwowym Konserwatorium Muzycznym (od 1946 r. Państwowej Wyższej Szkole Muzycznej), Państwowej Wyższej Szkole Sztuk Plastycznych, Wyższej Szkole Nauk Administracyjnych, Studium Pedagogicznym, Wyższej Szkole Gospodarstwa Wiejskiego i filii warszawskiej Szkoły Głównej Handlowej.

Wyższa Szkoła Gospodarstwa Wiejskiego działała tylko do 1950 r., natomiast filia Szkoły Głównej Handlowej w 1949 r. przyjęła nazwę filii Szkoły Głównej Planowania i Statystyki, w 1950 r. przekształconej w Wyższą Szkołę Ekonomiczną, a od 1 września 1961 r. włączonej do UŁ jako Wydział Ekonomiczno-Socjologiczny. W uruchomionych w 1945 r. dziewięciu wyższych uczelniach (rys. 1) studiowało blisko 10 tys. studentów (rys. 2) i do 1948 r. ich liczba wzrastała średnio o 2 tys. osób. Wtedy było w Łodzi już jedenaście uczelni, gdyż w 1946 r. zainaugurowały zajęcia Państwowa Wyższa Szkoła Teatralna i Państwowa Wyższa Szkoła Pedagogiczna (Jałmużna 1996), a w 1948 r. - Wyższa Szkoła Filmowa, która po dwóch latach otrzymała uprawnienia akademickie jako Państwowa Szkoła Filmowa (Krubski i in. 1998). Należy wspomnieć, że po wyzwoleniu, ze względu na ogromne zniszczenia Warszawy, do Łodzi przeniesiono niektóre szkoły wyższe i półwyższe, przygotowujące kadry administracyjne i polityczne dla odbudowującego się w nowym ustroju państwa, w tym m.in. Centralną Szkołę Ministerstwa Bezpieczeństwa Publicznego, Centralną Szkołę Oficerów Liniowych Milicji Obywatelskiej, Centralną Szkołę Polityczną, Szkołę Prawniczą Ministerstwa Sprawiedliwości i Szkołę Felczerów Wojsk Medycznych (Wolaniuk 1997).

W 1952 r. na Uniwersytecie Łódzkim zorganizowano Studium Języka Polskiego dla Cudzoziemców, które przez trzydzieści lat było jedyną w Polsce placówką nauczającą obcokrajowców języka polskiego. Ukończenie tam rocznego kursu języka polskiego umożliwiało obcokrajowcom rozpoczęcie studiów na polskich uczelniach. Obecnie Studium ma charakter naukowo-dydaktyczny.

W latach 1950-1954 w województwie łódzkim funkcjonowało dziesięć wyższych uczelni - wszystkie miały siedziby w Łodzi. Po kilku latach niektóre $\mathrm{z}$ nich zamknięto lub przeniesiono $\mathrm{z}$ powrotem do Warszawy. W związku z tym w latach 1961-1989 w województwie (tj. w Łodzi) działało tylko sześć uczelni (rys. 1). Były to: Uniwersytet Łódzki, Politechnika Łódzka, Akademia Medyczna, Akademia Sztuk Pięknych, Akademia Muzyczna oraz Państwowa Wyższa Szkoła Filmowa, Telewizyjna i Teatralna im. Leona Schillera. Roczna liczba ich absolwentów wzrosła z około 2 tys. osób (1961 r.) do 5,2 tys. w 1979 r., po czym spadła poniżej 3 tys. osób w 1989 r. (rys. 3).

W pierwszych powojennych latach sytuacja lokalowa łódzkich wyższych uczelni była bardzo trudna. Mieściły się w budynkach poprzemysłowych, szkołach średnich, hotelach, a nawet w kamienicach, gdyż Łódź jako miasto wojewódzkie i mało zniszczone nie otrzymywało od władz centralnych środków na budowę nowych obiektów. Tymczasem z dniem 1 stycznia 1950 r. z Uniwersytetu Łódzkiego wyłączono wydziały medyczne, tworząc z nich Akademię Medyczną, a w 1958 r. powstała w mieście druga - Wojskowa Akademia Medyczna im. gen. dyw. Bolesława Szareckiego ${ }^{2}$.

\footnotetext{
${ }^{2}$ Ze względów strategicznych w statystykach wojewódzkich i ogólnopolskich nie jest uwzględniana Wojskowa Akademia Medyczna im. gen. dyw. Bolesława Szareckiego, która również została pominięta w niniejszym opracowaniu. Nie ma też danych o Wyższym Seminarium Duchownym.
} 


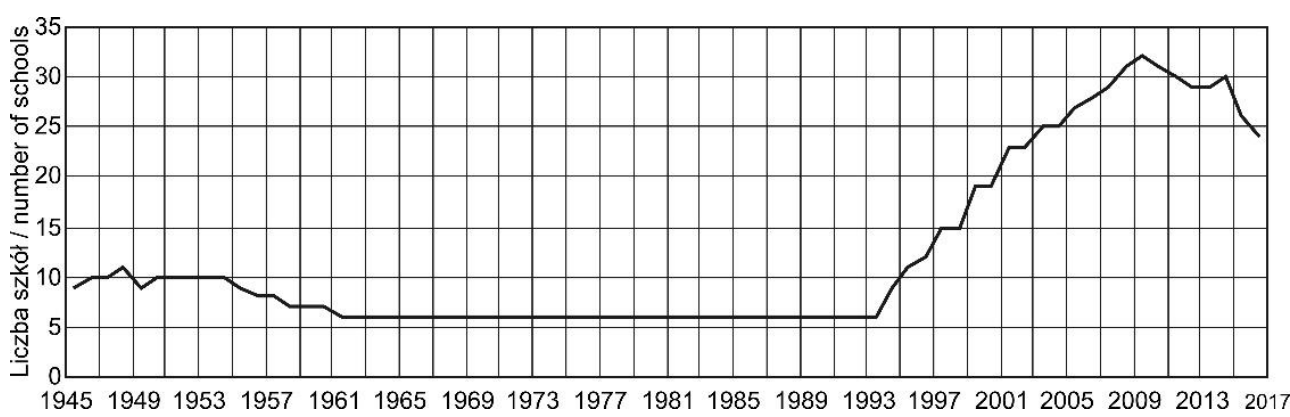

Rys. 1. Liczba szkół wyższych w województwie łódzkim w latach 1945-2017

(za: Rocznik Statystyczny Miasta Łodzi 1966, Roczniki Statystyczne Województwa Łódzkiego, WUS)

Number the higher education institutions in the Łódź Voivodeship, 1945-2017

(after: Rocznik Statystyczny Miasta Łodzi 1966, Roczniki Statystyczne Województwa Łódzkiego, WUS)

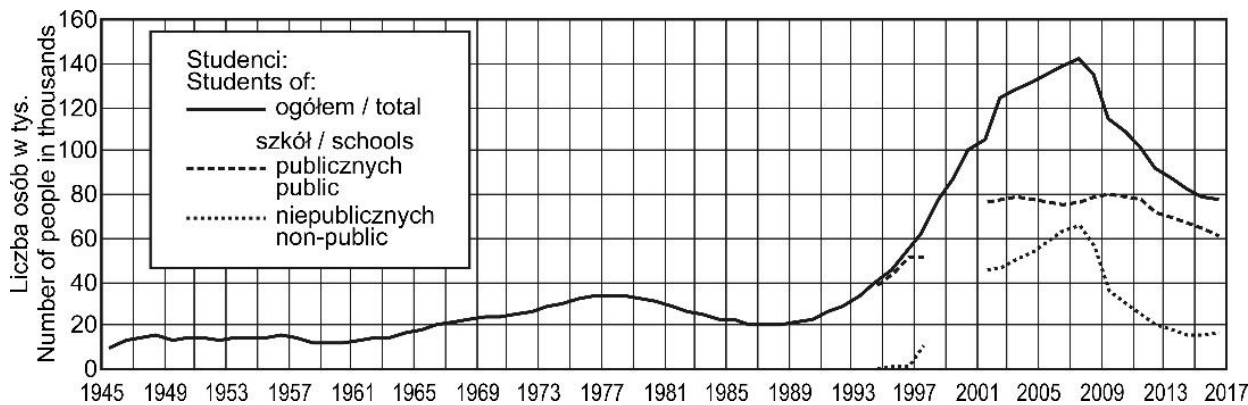

Rys. 2. Liczba studentów wyższych uczelni w województwie łódzkim w latach 1945-2017, z uwzględnieniem organów prowadzących po $1993 \mathrm{r}$.

(za: Rocznik Statystyczny Miasta Łodzi 1966, Roczniki Statystyczne Województwa Łódzkiego, WUS)

Number of university students in the Łódź Voivodeship (1945-2017) according to school governing authorities (since 1993)

(after: Rocznik Statystyczny Miasta Łodzi 1966, Roczniki Statystyczne Województwa Łódzkiego, WUS)

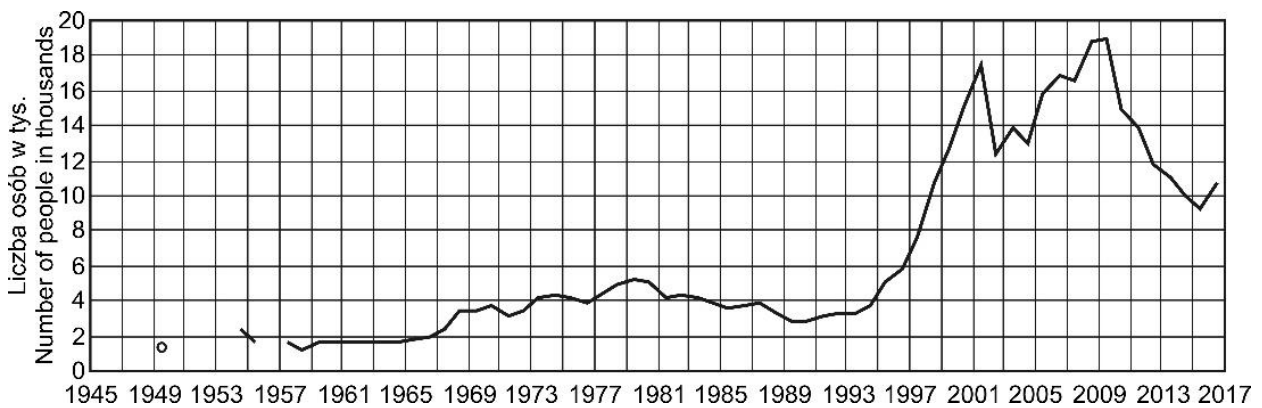

Rys. 3. Absolwenci wyższych uczelni w województwie łódzkim w latach 1949-2017

(za: Rocznik Statystyczny Miasta Łodzi 1966, Roczniki Statystyczne Województwa Łódzkiego, WUS)

Graduates of higher education institutions in the Łódź Voivodeship, 1949-2017

(after: Rocznik Statystyczny Miasta Łodzi 1966, Roczniki Statystyczne Województwa Łódzkiego, WUS)

Ta jedyna w Polsce wojskowa uczelnia medyczna, w 2002 r. została połączona z dawną uniwersytecką Akademią Medyczną, tworząc Uniwersytet Medyczny. Natomiast do UŁ włączono w 1956 r. Wyższą Szkołę Pedagogiczną, a w 1961 r. - Wyższą Szkołę Ekonomiczną.
Z kolei w 1958 r. doszło do połączenia Wyższej Szkoły Teatralnej i Wyższej Szkoły Filmowej, od 1 stycznia 1959 r. przyjęły one wspólną nazwę Państwowej Wyższej Szkoły Teatralnej i Filmowej im. L. Schillera, a 10 lat później Państwowej Wyższej Szkoły Filmowej, Telewizyjnej i Teatral- 
nej im. L. Schillera (PWSFTviT). Państwowej Wyższej Szkole Muzycznej nadano w 1982 r. nazwę Akademii Muzycznej, a w 1999 r. przyjęła ona nazwę Akademii Muzycznej im. Grażyny i Kiejstuta Bacewiczów (AMUZ), natomiast Państwowa Wyższa Szkoła Sztuk Plastycznych przyjęła imię Władysława Strzemińskiego, a od 1996 r. stała się Akademią Sztuk Pięknych (ASP) imienia tego słynnego rzeźbiarza.

Reforma administracyjna z 1.06.1975 r. 12-krotnie zmniejszyła obszar, a o $60 \%$ zaludnienie województwa łódzkiego. Wtedy też m.in. Piotrków Trybunalski stał się siedzibą województwa, a po sześciu latach (w 1981 r.) otwarto tam Wydział Zamiejscowy Wyższej Szkoły Pedagogicznej z Kielc. Kolejna zmiana granic administracyjnych województwa łódzkiego (z dnia 1 stycznia 1999 r.) ponownie włączyła Piotrków Trybunalski do województwa łódzkiego - jako jeden z nowych ośrodków kształcenia na poziomie uniwersyteckim.
Trwające od XIX w. zabiegi o utworzenie w stolicy województwa łódzkiego uczelni wyższej, wielkie oczekiwania młodzieży na rozpoczęcie studiów wyższych sprawiły, że w roku 1945 r. studia podjęło blisko 10 tys. osób, a na jednego studenta przypadało 152 mieszkańców województwa (tab. 1). Z każdym rokiem wzrastała liczba studentów, przy czym gros nauczycieli akademickich pochodziło z Warszawy, Krakowa, Poznania, a także ze Lwowa i Wilna. Część profesorów po kilku latach powróciła do swoich ośrodków macierzystych, lecz pozostali włączyli się w budowę łódzkiej kadry akademickiej. Dlatego też do lat 80 . XX w. największą grupę wśród nauczycieli akademickich stanowili asystenci, a dopiero od lat 90. - adiunkci (rys. 4). Ponieważ rozwój naukowy nauczyciela akademickiego wymaga wielu lat, w okresie PRL szybciej rosła liczba docentów (w tym tzw. mianowanych) aniżeli profesorów.

Tabela 1

Rozwój szkolnictwa wyższego w województwie łódzkim w latach 1945-2017

(za: Roczniki Statystyczne Województwa Łódzkiego)

Development of higher education in the Lódź Voivodeship, 1945-2017

(after: Roczniki Statystyczne Województwa Łódzkiego)

\begin{tabular}{|c|c|c|c|c|c|}
\hline \multirow[b]{3}{*}{$\begin{array}{l}\text { Lata } \\
\text { Years }\end{array}$} & \multirow{3}{*}{$\begin{array}{l}\text { Liczba szkół wyż- } \\
\text { szych } \\
\text { Number of higher } \\
\text { education institu- } \\
\text { tions }\end{array}$} & \multicolumn{3}{|c|}{ Liczba studentów Number of students } & \multirow{3}{*}{$\begin{array}{l}\text { Liczba mieszkańców } \\
\text { na } 1 \text { studenta } \\
\text { Number of inhabitants } \\
\text { per student }\end{array}$} \\
\hline & & \multicolumn{2}{|c|}{ ogółem total } & \multirow{2}{*}{$\begin{array}{c}\text { na jednego } \\
\text { nauczyciela } \\
\text { akademickiego } \\
\text { for one academic } \\
\text { teacher }\end{array}$} & \\
\hline & & $\begin{array}{c}\text { osób } \\
\text { persons }\end{array}$ & $\begin{array}{l}\text { dynamika } \\
\text { dynamies } \\
1945=100\end{array}$ & & \\
\hline 1945 & 9 & 9981 & $100 \%$ &. & 152,1 \\
\hline 1950 & 10 & 14435 & 144,6 & . & 102,0 \\
\hline 1955 & 10 & 14293 & 143,2 & . & 107,5 \\
\hline 1960 & 7 & 12449 & 124,7 & 7,3 & 129,9 \\
\hline 1965 & 6 & 18182 & 182,2 & 9,0 & 91,6 \\
\hline 1970 & 6 & 24225 & 242,7 & 8,9 & 42,6 \\
\hline$* 1975$ & 6 & 32458 & 325,2 & 8,8 & 33,2 \\
\hline 1980 & 6 & 30920 & 309,8 & 7,3 & 36,5 \\
\hline 1985 & 6 & 22157 & 222,0 & 4,9 & 51,9 \\
\hline 1989 & 6 & 22084 & 221,3 & 4,8 & 51,7 \\
\hline 1990 & 6 & 22894 & 229,4 & 4,9 & 49,8 \\
\hline 1995 & 11 & 45332 & 454,2 & 9,7 & 59,3 \\
\hline 2000 & 19 & 100142 & 1003,3 & 17,1 & 26,2 \\
\hline 2005 & 27 & 134366 & 1346,2 & 18,6 & 19,2 \\
\hline 2010 & 31 & 108221 & 1084,3 & 14,9 & 23,2 \\
\hline 2015 & 26 & 79388 & 795,4 & 12,7 & 31,4 \\
\hline 2017 & 23 & 85170 & 853,3 & 13,6 & 29,1 \\
\hline
\end{tabular}

* kursywą zaznaczono lata 1975-98, w których 6-krotnie zmniejszono powierzchnię województwa łódzkiego

* italics indicate the years 1975-98, in which the area of the Łódź Voivodeship was reduced six times 


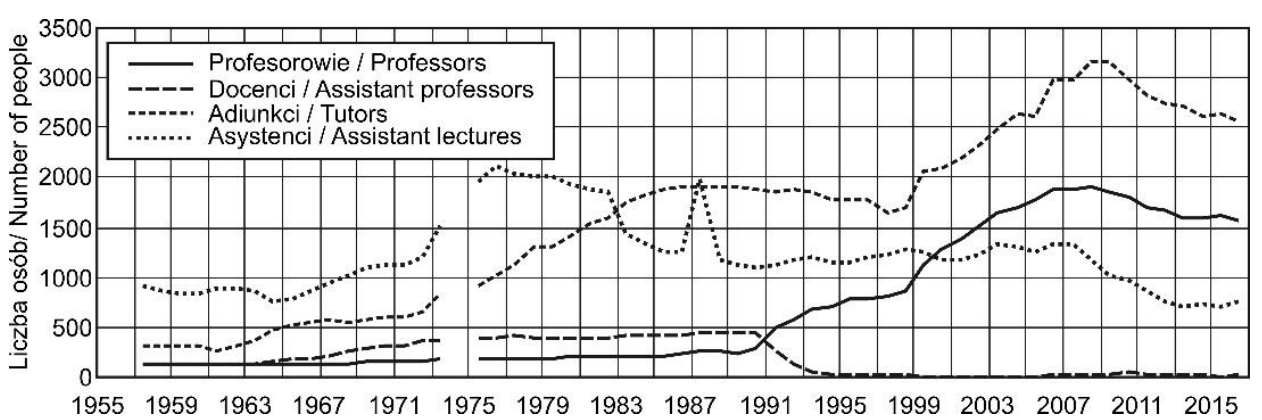

Rys. 4. Struktura nauczycieli akademickich w wyższych uczelniach w województwie łódzkim w latach 1957-2017 (za: Roczniki Statystyczne Województwa Łódzkiego, WUS)

Structure of academic teachers at higher education institutions of the Łódź Voivodeship, 1957-2017 (after: Roczniki Statystyczne Województwa Łódzkiego, WUS)

Przez pierwsze 5 lat funkcjonowania łódzkich uczelni, absolwentami byli wyłącznie studenci studiów stacjonarnych (rys. 4), a absolwenci studiów zaocznych pojawili się dopiero w latach 60. XX w. (Liszewski i in. 2008). Ogólna liczba studentów w Łodzi najszybciej wzrastała do 1975 r., wskaźnik wzrostu w tamtym roku w stosunku do 1945 r. wyniósł ponad $325 \%$ (tab. 1), a studenci niestacjonarni stanowili w tym prawie $40 \%$. Ze względu na specyfikę studiów najmniej było ich w uczelniach artystycznych, zwłaszcza w PWSFTviT i AMUZ.

Po pewnym nasyceniu rynku pracy absolwentami wyższych uczelni, od 1960 r. w województwie łódzkim w strukturze studentów wyższych uczelni znów dominowali studenci studiów dziennych.

W latach 1960-1989 spadła liczba studentów (z 7,3 do 4,9) przypadająca na jednego nauczyciela akademickiego, co było wynikiem wspomnianego rozwoju kadry akademickiej, a także wzrostu poziomu kształcenia. Należy nadmienić, że liczba studentów przypadających na jednego nauczyciela akademickiego $\mathrm{w}$ województwie łódzkim była jednak zawsze poniżej średniej krajowej.

Szybki rozwój szkolnictwa wyższego w Łodzi przyczynił się do wzrostu udziału pracowników naukowych w zatrudnieniu ludności miasta, a także województwa. W latach 60. pracownicy szkół wyższych stanowili $0,9 \%$ ogółu zatrudnionych w Łodzi, a po 30 latach - prawie 3\% (Wolaniuk 1997). Gwałtowne uprzemysłowienie zwiększyło zapotrzebowanie na kadry inżynierskie, czego efektem było uruchomienie przez
Politechnikę Łódzką w 1969 r. Filii w BielskuBiałej, która w 2001 r. stała się samodzielną uczelnią.

W latach 1945-1989 władze uczelni i miasta stanęły przed ogromnym wyzwaniem, jakim była budowa zaplecza dydaktycznego dla łódzkich wyższych uczelni. Poza nowymi kompleksami dydaktycznymi m.in. budynku wydziału architektury dla Politechniki, wydziałów biologii, fizyki i matematyki dla UŁ oraz kompleksu ASP oddano do użytku domy studenckie. W rezultacie, w przestrzeni Łodzi pojawił się kampus Politechniki przylegający do południowo-zachodniej części Śródmieścia, a położony na terenie starej dzielnicy przemysłowej, kompleks ASP w północno-wschodniej części miasta i kampus UŁ w północno-wschodnim rejonie Śródmieścia. Do obiektów dydaktycznych UŁ, jak i akademików Politechniki, UŁ i Uniwersytetu Medycznego na osiedlu studenckim UŁ (powszechnie zwanym Lumumbowem ${ }^{3}$ ) doprowadzono linię tramwajową, która połączyła to osiedle akademickie m.in. ze Śródmieściem i dworcami kolejowymi. W 1975 r. rozpoczęto budowę największego obiektu akademickiego w Łodzi - Centrum Kliniczno-Dydaktycznego (CKD) Uniwersytetu Medycznego, która trwała aż 38 lat. CKD zlokalizowane jest na wschód od Śródmieścia, stanowi przedłużenie kampusu uniwersyteckiego. Obecność wyższych uczelni i ich absolwentów przyczyniła się do podniesienia prestiżu miasta, nie tylko w Polsce, lecz także na arenie międzynarodowej.

\footnotetext{
${ }^{3}$ Nazwa ta pochodzi od nazwiska pierwszego premiera niepodległego Konga (byłego Belgijskiego), Patryka Lumumby, a związana była z zamieszkującymi na tym osiedlu zagranicznymi słuchaczami (w tym także Afrykanami) wspomnianego wcześniej Studium Języka Polskiego dla Cudzoziemców.
} 


\section{Szkolnictwo wyższe \\ w województwie lódzkim \\ po powrocie do gospodarki \\ wolnorynkowej w latach 1990-2019}

W 1990 r. w Łodzi funkcjonowało sześć publicznych szkół wyższych, na których studiowało blisko 23 tys. studentów (w tym 295 obcokrajowców) pod kierunkiem 4638 nauczycieli akademickich. W wojewódzkim wtedy mieście, w Piotrkowie Trybunalskim, nadal funkcjonował Wydział Zamiejscowy Wyższej Szkoły Pedagogicznej w Kielcach im. Jana Kochanowskiego, przekształcony w 2000 r. w Filię Uniwersytetu Jana Kochanowskiego.

Uruchomienie procesów wolnorynkowych po wyborach z 4 czerwca 1989 r. zaowocowało powstawaniem w Polsce licznych szkół niepublicznych. Pierwsze w niewielkim wówczas miejskim województwie łódzkim takie uczelnie otwarto w 1993 r. W Łodzi była to Wyższa Szkoła Humanistyczno-Ekonomiczna, którą w marcu 2009 r. przekształcono w Akademię Humanistyczno-Ekonomiczną, a w Łowiczu (woj. skierniewickie) powołano Mazowiecką Wyższą Szkołę Humanistyczno-Pedagogiczną (zamknięto ją w 2015 r.). Rok później rozpoczęły działalność dwie szkoły: Wyższa Szkoła Marketingu i Biznesu i Wyższa Szkoła Kupiecka (obecnie zamknięta), która przez kilka lat miała swoją siedzibę w Zgierzu, a rektorat i obiekty dydaktyczne mieściły się w pobliskiej Łodzi. W 1995 r. powołano w Łodzi Społeczną Wyższą Szkołę Przedsiębiorczości i Zarządzania (obecnie Społeczna Akademia Nauk) i Wyższą Szkołę Administracji Publicznej (zakończyła działalność 30 września 2010 r.), a w 1996 r. - Salezjańską Wyższą Szkołę Ekonomii i Zarządzania (obecnie Szkoła Wyższa Ekonomii i Zarządzania). W wojewódzkim wtedy mieście - Skierniewicach powstała Wyższa Szkoła Ekonomiczno-Humanistyczna im. prof. S.A. Pieniążka (działała do 2018 r.). Z kolei w 1997 r. powołano w Łodzi Wyższą Szkołę Informatyki (obecnie Wyższa Szkoła Informatyki i Umiejętności), Wyższą Szkołę Finansów, Bankowości i Ubezpieczeń im. Prof. Janusza Chechlińskiego oraz Wyższą Szkołę Studiów Międzynarodowych. Natomiast w Kutnie (wówczas woj. płockie) powstała w 1998 r. Wyższa Szkoła Gospodarki Krajowej, która jako jedyna działa w północnej części obecnego, ponownie (od 1999 r.) dużego województwa łódzkiego. W 2000 r. powstały w Łodzi dalsze dwie uczelnie: Wyższa Szkoła Sztuki i Projektowania (obecnie w likwidacji) oraz
Wyższa Szkoła Turystyki i Hotelarstwa (od 2007 r. posiadała ona ośrodek zamiejscowy w Gostyninie), którą 21 listopada 2012 r. włączono do Szkoły Głównej Turystyki i Rekreacji w Warszawie. W 2002 r. powołano w Łodzi Wyższą Szkołę Edukacji Zdrowotnej, w 2003 r. Wyższą Szkołę Pedagogiczną (obecnie zamkniętą), a w 2004 r. Wyższą Szkołę Zawodową Łódzkiej Korporacji.

W Piotrkowie Trybunalskim w latach 20032018 funkcjonowała Wyższa Szkoła Handlowa im. Króla Stefana Batorego, którą później zastąpiła Filia Wyższej Szkoły Handlowej z Radomia (obecnie prowadzi wyłącznie studia podyplomowe). Dwa lata później powołano w Łodzi Wyższą Szkołę Humanistyczną Wschód-Zachód, w 2007 r. Wyższą Szkołę Biznesu i Nauk o Zdrowiu, w 2008 r. - Wyższą Szkołę Sportową im. Kazimierza Górskiego (obecnie zamkniętą) i Wyższą Szkołę COSINUS. Najmłodszą łódzką uczelnią niepubliczną jest Uczelnia Nauk Społecznych otwarta w $2013 \mathrm{r}$.

Wraz z rozwojem szkolnictwa niepublicznego doszło do swoistej dyfuzji placówek UŁ i PŁ. W 1998 r. powstała w Tomaszowie Mazowieckim Filia UŁ oraz zamiejscowe ośrodki dydaktyczne tego uniwersytetu w Kutnie, Piotrkowie Trybunalskim, Sieradzu i Skierniewicach, a także w wojewódzkiej wówczas Ostrołęce (obecnie województwo mazowieckie). Politechnika Łódzka poza wspomnianą filią w BielskuBiałej posiadała jednostki zamiejscowe w Bełchatowie, Sieradzu, Wieruszowie, Zduńskiej Woli i Żychlinie.

W sumie, w roku akademickim 1999/2000, dwadzieścia jeden niepublicznych łódzkich szkół wyższych działało w 12 miastach województwa łódzkiego, w tym jedenaście w Łodzi, cztery w Łowiczu, po dwa w Zgierzu i Sieradzu oraz po jednej w Kutnie, Skierniewicach, Rawie Mazowieckiej, Opocznie, Piotrkowie Trybunalskim, Sieradzu, Poddębicach, Pabianicach i Lasku (Wolaniuk 2001).

Koniec XX w. związany był $\mathrm{z}$ ożywioną działalnością zewnętrzną szkół niepublicznych, a szczególnie łódzkiej Wyższej Szkoły Humanistyczno-Ekonomicznej, która otworzyła punkty konsultacyjne w Opocznie, Sieradzu, Poddębicach, Pabianicach a także poza granicami województwa: w Koninie i Kaliszu. Wyższa Szkoła Kupiecka prowadziła punkty zamiejscowe w Rawie Mazowieckiej, Piotrkowie Trybunalskim i Sieradzu, a Społeczna Wyższa Szkoła Przedsiębiorczości i Zarządzania w Ostrowie koło Łasku.

Ze względu jednak na brak zaplecza akademickiego i spadek liczby młodzieży w wieku 
studenckim większość tych placówek po kilku latach przestała funkcjonować. Podobny los spotkał uczelnie wyższe mające swoje siedziby poza województwem łódzkim. Upadły też filie i jednostki zamiejscowe uczelni wyższych spoza województwa łódzkiego m.in. Filia Politechniki Częstochowskiej w Radomsku, jednostki zamiejscowe Wrocławskiej Akademii Rolniczej w Zduńskiej Woli i Lututowie oraz SGGW w Widzewie i Łowiczu. Natomiast w 2005 r. w Skierniewicach rozpoczęła działalność akademicka Państwowa Wyższa Szkoła Zawodowa.

W roku akademickim 2003/2004, dwie łódzkie uczelnie publiczne (UŁ i PŁ) oraz pięć niepublicznych prowadziły zajęcia dydaktyczne $\mathrm{w}$ dwudziestu dziewięciu placówkach zamiejscowych w 22 miastach 6 województw (rys. 5). Najwięcej ich (4) działało w Sieradzu, a poza województwem łódzkim - po dwie były w Bydgoszczy i Ostrowie Wielkopolskim. Z uczelni publicznych bardziej ekspansywny był UŁ, który prowadził sześć zamiejscowych ośrodków dydaktycznych w: Sieradzu, Skierniewicach, Kutnie, Ostrołęce i Piotrkowie Trybunalskim oraz Filię w Tomaszowie Mazowieckim. Politechnika Łódzka miała zaś trzy takie ośrodki - w Sieradzu, Zduńskiej Woli i w Ostrowie Wielkopolskim. Ze szkół niepublicznych, najwięcej ośrodków zamiejscowych (po 4) prowadziły: Społeczna Wyższa Szkoła Przedsiębiorczości i Zarządzania (obecnie Społeczna Akademia Nauk): w Brodnicy, Garwolinie, Kołobrzegu i Ostrowi Mazowieckiej oraz zlikwidowana już Wyższa Szkoła Kupiecka, a także (2) Wyższa Szkoła Humanistyczno-Ekonomiczna, obecna Akademia Humanistyczno-Ekonomiczna (rys. 5).

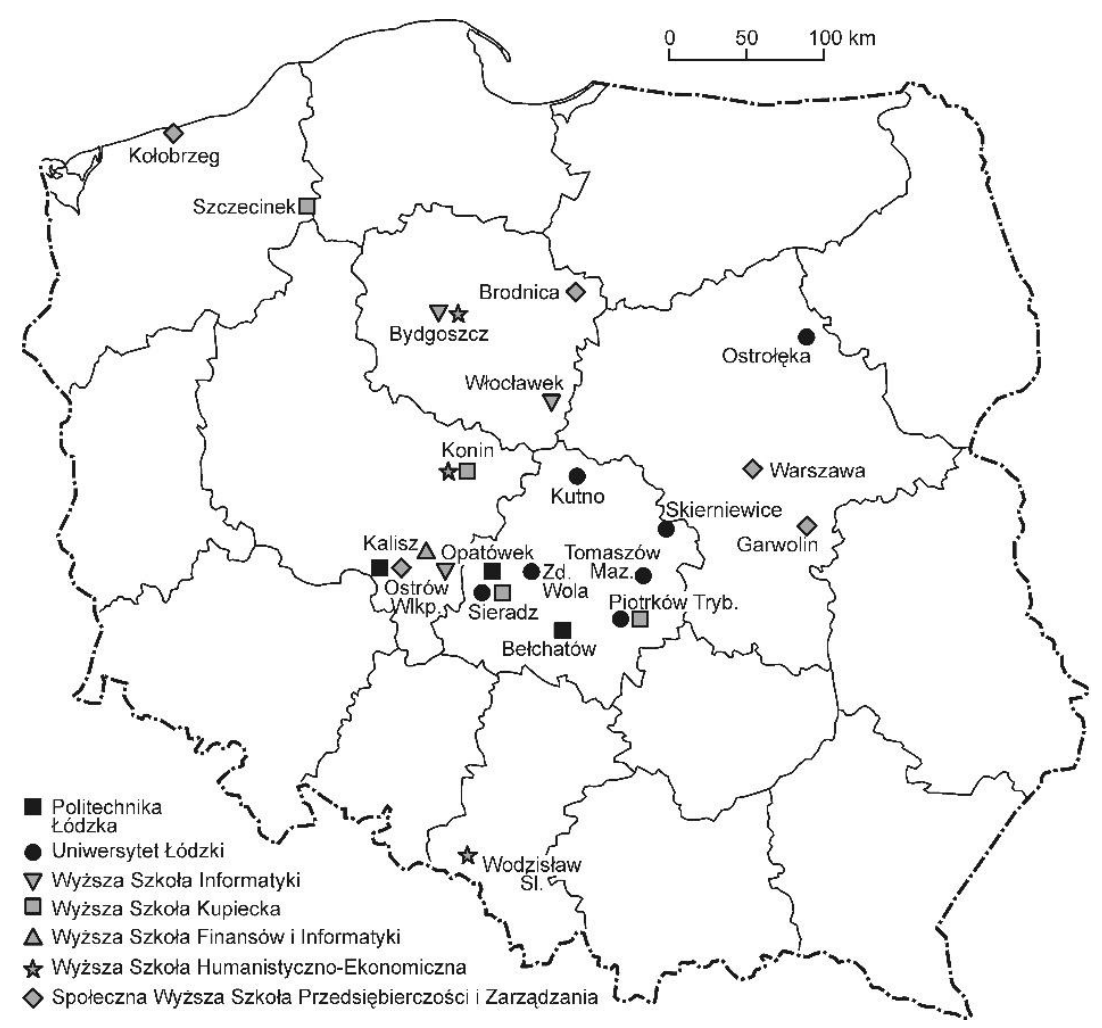

Rys. 5. Zamiejscowe ośrodki dydaktyczne siedmiu uczelni łódzkich w roku akademickim 2003/2004 (za: Wolaniuk 2006)

Branches of seven Łódź universities in the academic year 2003/04 (after: Wolaniuk 2006)

Szybki rozwój niepublicznego szkolnictwa wyższego w województwie łódzkim sprawił, że w XXI w. wzrosła znacznie liczba studentów przypadających na jednego nauczyciela akademickiego do wartości 18,6 w 2005 r., po czym zaczęła stopniowo maleć. W 2017 r. wartość tego wskaźnika w 28 państwach Unii Europejskiej wyniosła 9,8
(eu.europaeu/Eurostat/statistics/Tertiary_education _statistic_ YB2017, data wejścia 15.11.2018), w Polsce 13,5 - a w województwie łódzkim 13,6, podczas gdy dla Polski wynosiła 14. Liczba studentów przypadająca na jednego nauczyciela akademickiego była więc w województwie łódzkim nieco poniżej średniej krajowej (Szkoły wyższe... 2018). 
Od 2008 r. spadła liczba nauczycieli akademickich zatrudnionych w szkołach wyższych województwa z 7,8 tys. osób do 6,3 tys. w $2018 \mathrm{r}$. Uwzględniając jednak ogół wszystkich pracowników w szkolnictwie wyższym w województwie łódzkim stwierdzamy, że szkoły wyższe należą tu do najważniejszych pracodawców.

W XXI w. doszło do zmian w sieci niepublicznych szkół wyższych. Niektóre placówki zamknięto, jednak w ich miejsce powstały nowe, oferujące „modniejsze” kierunki, lepiej odpowia- dające na zapotrzebowanie rynku pracy aniżeli uczelnie publiczne. W roku akademickim 2007/2008 studiowała w województwie łódzkim największa liczba studentów (142,5 tys. osób), a rok później tamtejsze uczelnie ukończyło najwięcej absolwentów - 18,7 tys. osób. W tym roku w Łodzi działały dwadzieścia dwie szkoły wyższe, w Piotrkowie Trybunalskim - sześć, w Zduńskiej Woli i Sieradzu - po cztery, w Kutnie i Skierniewicach - po dwie, w Radomsku i Wieluniu - po jednej (rys. 6).

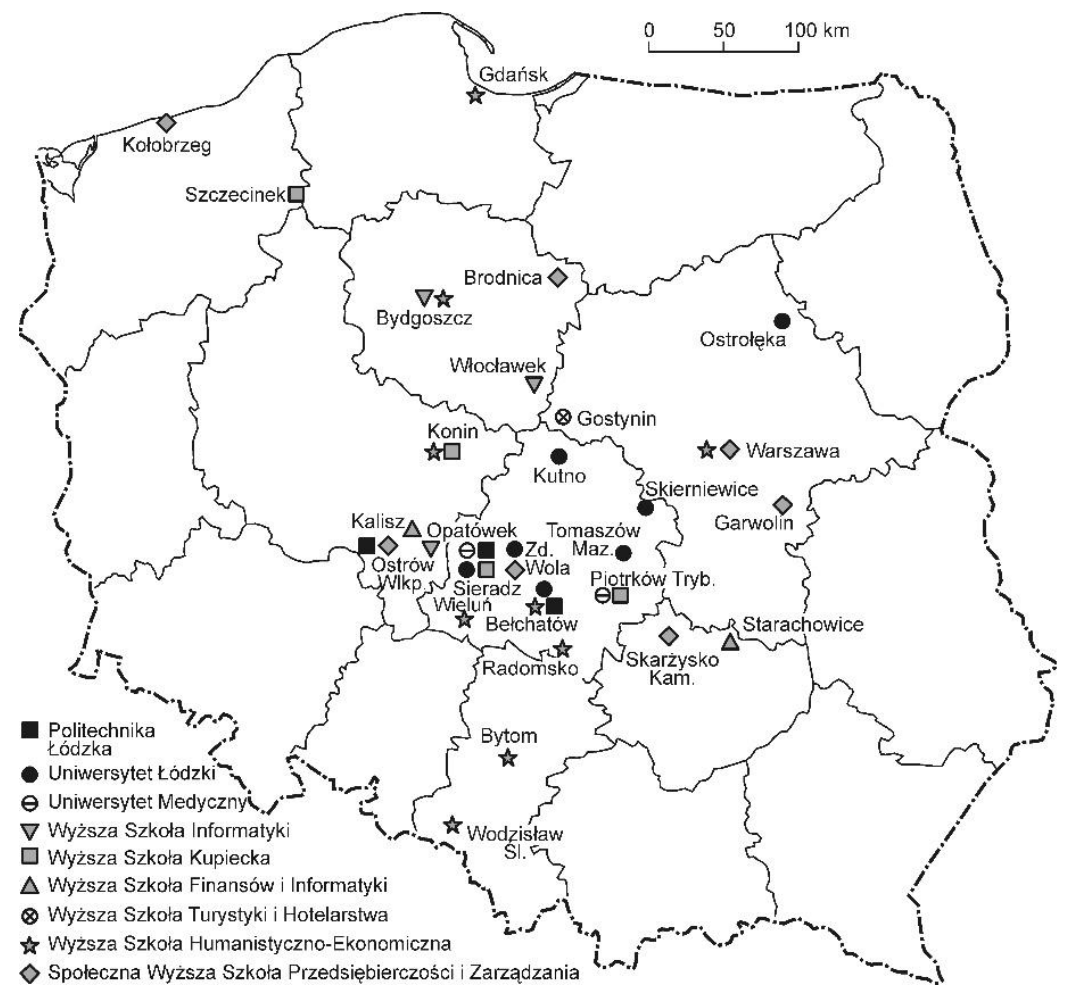

Rys. 6. Zamiejscowe ośrodki dydaktyczne łódzkiego ośrodka akademickiego w r. ak. 2007/2008 (za: Liszewski i in. 2008)

Branches of Łódź universities in the academic year 2007/08 (after: Liszewski et al. 2008)

Uczelnie w województwie łódzkim zatrudniały wtedy najwięcej pracowników dydaktycznych, wśród których dominowali adiunkci stanowiący ponad $40 \%$ nauczycieli akademickich; udział profesorów wynosił $25 \%$, a asystentów $15,2 \%$ (rys. 4). Nieliczna grupa docentów występowała przede wszystkim w szkołach niepublicznych. Liczba studentów w uczelniach niepublicznych wzrastała do 2008 r., osiągając liczbę blisko 66 tys., a następnie zaczęła spadać do około 17 tys. w 2018 r. Jednak w latach akademickich 2001/2002 i 2004/2005 - 2008/2009 szkoły niepubliczne skupiały jeszcze ponad $40 \%$ ogółu studentów w województwie łódzkim (rys. 2). Liczba studentów w uczelniach publicznych natomiast w 2010 r. osiągnęla blisko 80 tys., a w kolejnych latach znacznie spadła do 61 tys. Od 2010 r. uczelnie publiczne skupiały ponad 70\% ogółu studentów w województwie. Liczba studentów III stopnia (słuchaczy studiów doktoranckich) utrzymuje się na stałym poziomie, około $2,5-3$ tys. osób rocznie.

W roku akademickim 2007/2008 lódzkie szkoły wyższe dysponowały trzydziestoma ośrodkami zamiejscowymi w 26 miastach i jednej wsi (Opatówek; WSI), aż w siedmiu województwach (Liszewski i in. 2008). Wiele niepublicznych szkół prowadziło placówki zamiejscowe w bardzo oddalonych od Łodzi miastach (rys. 6).

Z sześciu wyższych szkół niepublicznych najwięcej ośrodków zamiejscowych, bo sześć posiadała Wyższa Szkoła Humanistyczno-Ekonomiczna (obecnie AHE): w Bydgoszczy, Bytomiu, Gdańsku, 
Koninie, Warszawie i Wodzisławiu Śląskim oraz pięć Społeczna Wyższa Szkoła Przedsiębiorczości i Zarządzania (obecnie SAN): w Brodnicy, Garwolinie, Kołobrzegu, Ostrowiu Wielkopolskim i Warszawie. Wyższa Szkoła Kupiecka (obecnie zamknięta) kształciła studentów I stopnia w Koninie, Piotrkowie Tryb. Sieradzu i Szczecinku, Wyższa Szkoła Informatyki (obecnie WSIiU) prowadziła studia licencjackie w Bydgoszczy, Włocławku i Opatówku, Wyższa Szkoła Finansów i Informatyki posiadała dwa ośrodki zamiejscowe: w Kaliszu i Starachowicach, a nieistniejąca już od kilku lat Wyższa Szkoła Turystyki w Gostyninie.

Uczelnie publiczne, w tym UM, PŁ i UŁ posiadały łącznie osiem zamiejscowych ośrodków dydaktycznych. Uniwersytet Medyczny prowadził ośrodki zamiejscowe w Piotrkowie Trybunalskim i Sieradzu, Politechnika Łódzka w Bełchatowie, Ostrowie Wielkopolskim i Sieradzu, a Uniwersytet Łódzki w Kutnie, Ostrołęce, Sieradzu i Filię w Tomaszowie Mazowieckim. Zasięg oddziaływania szkół wyższych województwa łódzkiego był znaczący w skali kraju. Świadczy to silnej funkcji egzogenicznej realizowanej przez łódzkie szkoły wyższe.

W roku akademickim 2018/2019, w którym obchodziliśmy 100-lecie województwa łódzkiego, inauguracja roku akademickiego odbyła się w 11 miastach województwa, w ośmiu uczelniach publicznych i szesnastu niepublicznych (tab. 2; rys. 7 , 8). Publiczne szkoły wyższe do 2013 r. zamknęły swoje zamiejscowe ośrodki dydaktyczne, jedynie UŁ utrzymał Filię w Tomaszowie Mazowieckim, a Politechnika przygotowuje uruchomienie Centrum Zarządzania i Inżynierii Produkcji w Sieradzu. Mimo znacznego spadku liczby niepublicznych szkół wyższych, mających swoją siedzibę w Łodzi, zasięg ich oddziaływania poza granicami województwa łódzkiego nie uległ wcale zawężeniu. Czynne jeszcze niepubliczne uczelnie uruchomiły bowiem nowe zamiejscowe ośrodki dydaktyczne, chcąc pozyskać studentów spoza wyludniającego się województwa łódzkiego. Szkoły niepubliczne $\mathrm{z}$ siedzibami w Lodzi posiadały w roku akademickim 2018/2019 zamiejscowe ośrodki dydaktyczne aż w 24 miastach 11 województw! Jednocześnie w województwie łódzkim powstały wydziały zamiejscowe 3 uczelni położonych w ościennych województwach, jak np. wydział zamiejscowy w Tomaszowie Mazowieckim Wyższej Szkoły Biznesu i Przedsiębiorczości z Ostrowca Świętokrzyskiego otwarty w roku 2018/2019..

Trzeba więc podkreślić, że otwarcie w ostatniej dekadzie XX w. wielu wyższych szkół niepublicznych (zob. rys. 1) w województwie łódzkim (głów- nie w Lodzi) doprowadziło do nagłego wzrostu liczby studentów (zob. rys. 2, 3). Na jednego studenta w 1995 r. przypadało 59,3 mieszkańców województwa, a pięć lat później 26,2 (tab. 1).

W roku akademickim 2009/2010 działało w województwie łódzkim najwięcej szkół wyższych - 32, w tym tylko 6 uczelni publicznych. Jednak w okresie 2007/08-2016/17 liczba studentów w naszym województwie spadła o $54 \%$ - ze 142,5 tys. do 77,4 tys., po czym nieznacznie wzrosła, do ponad 85,2 tys. w roku akademickim 2017/2018.

Prestiż ośrodka akademickiego podnoszą studenci zagraniczni, których liczba w województwie łódzkim systematycznie wzrasta. W roku 2016/2017 obcokrajowcy studiujący w Uniwersytecie Łódzkim stanowili blisko 9\% ogółu takich studentów na polskich uniwersytetach, ci z Politechniki Łódzkiej - 8\% ogółu cudzoziemców studiujących w uczelniach technicznych, a z łódzkiego Uniwersytetu Medycznego - 10,3\% (w warszawskim UM 10,7\%). Natomiast w łódzkich wyższych uczelniach artystycznych obcokrajowcy stanowią aż 22,7\% ogółu obcokrajowców studiujących w Polsce, z których 7,3\% studiowało w PWSFTviT (Szkolnictwo wyższe... 2018). Łódzka „Filmówka", a szczególnie jej Wydział Reżyserii cieszy się w skali świata największą popularnością spośród polskich uczelni.

W roku akademickim 2018/2019 funkcja akademicka występuje więc w 9 miastach (rys. 8), podczas gdy przez ostatnie 10 lat obecna była w 13 . Ze względu na silnie zachodzące $\mathrm{w}$ województwie łódzkim procesy depopulacji, starzenia się społeczeństwa, w tym zmniejszającą się liczba młodzieży, zarówno Uniwersytet, jak i Politechnika zamknęły w 2013 r. swoje zamiejscowe ośrodki dydaktyczne. Ubyło także szkół niepublicznych, co także jest następstwem wspomnianych przemian demograficznych oraz wzrostem zainteresowania bezpłatnymi uczelniami publicznymi. Wśród działających jeszcze szkół niepublicznych wyróżniają się: Społeczna Akademia Nauk, oferująca m.in. amerykański lub francuski dyplom MASTER Clark Univeristy i MOD'SPE Paris oraz najstarsza w Łodzi Akademia Humanistyczno-Ekonomiczna, dysponująca nowoczesnymi salami dydaktycznymi w zrewitalizowanych obiektach poprzemysłowych na zapleczu UŁ i Teatru Wielkiego, łącznie ze studiem radiowym i telewizyjnym Arterion.

Pełen cykl kształcenia akademickiego obejmujący studia I stopnia (licencjackie), II stopnia (magisterskie) i doktoranckie (III stopnia) oraz podyplomowe (tab. 2) oferuje wszystkie sześć łódzkich uczelni publicznych oraz trzy niepubliczne: 
Szkoły wyższe w województwie łódzkim w roku akademickim 2018/2019

Higher education institutions in the Łódź Voivodeship in the academic year 2018/19

\begin{tabular}{|c|c|c|c|c|c|c|c|}
\hline \multirow{2}{*}{\multicolumn{2}{|c|}{$\begin{array}{l}\text { Nazwa szkoły } \\
\text { Name of the school }\end{array}$}} & \multirow{2}{*}{$\begin{array}{l}\text { Liczba } \\
\text { kierun } \\
\text { ków } \\
\text { Num- } \\
\text { ber of } \\
\text { direc- } \\
\text { tions }\end{array}$} & \multicolumn{4}{|c|}{$\begin{array}{l}\text { Rodzaj studiów } \\
\text { Type of studies }\end{array}$} & \multirow{2}{*}{$\begin{array}{c}\text { Filie }(\mathrm{F}), \text { Wydziały }(\mathrm{W}), \\
\text { Wydziały Zamiejscowe (WZ) } \\
\text { Branches }(F), \text { Departments }(W), \\
\text { Extramural Departments }(W Z)\end{array}$} \\
\hline & & & $\mathrm{I}^{\mathrm{o}}$ & $\mathrm{II}^{\mathrm{o}}$ & $\mathrm{III}^{\mathrm{o}}$ & $\begin{array}{l}\text { Podypl. } \\
\text { Postgrad. }\end{array}$ & \\
\hline \multicolumn{8}{|c|}{ Szkoły publiczne Public schools } \\
\hline 1 & Akademia Medyczna & 34 & + & + & + & + & \\
\hline 2 & Akademia Muzyczna & 9 & + & + & + & + & \\
\hline 3 & Akademia Sztuk Pięknych & 7 & + & + & + & + & \\
\hline 4 & Politechnika Łódzka & 41 & + & + & + & + & WZ: Sieradz \\
\hline 5 & $\begin{array}{l}\text { Państwowa Wyższa Szkoła } \\
\text { Filmowa, Telewizyjna i Teatralna }\end{array}$ & 4 & + & + & + & + & \\
\hline 6 & Uniwersytet Łódzki & 116 & + & + & + & + & F: Tomaszów Maz. \\
\hline 7 & $\begin{array}{l}\text { Państowa Wyższa Szkoła } \\
\text { Zawodowa w Skierniewicach }\end{array}$ & 12 & + & + & & + & \\
\hline 8 & $\begin{array}{l}\text { Uniwersytet Jana Kochanowski- } \\
\text { ego w Kielcach; Filia w Piotrko- } \\
\text { wie Tryb. }\end{array}$ & 7 & + & + & & & \\
\hline \multicolumn{8}{|c|}{ Szkoły niepubliczne Non-public schools } \\
\hline 1 & $\begin{array}{l}\text { Akademia Humanistyczno- } \\
\text { Ekonomiczna w Łodzi }\end{array}$ & 20 & + & + & + & + & $\begin{array}{l}\text { F: Jasło, Trzcianka, Warszawa, } \\
\text { Wodzisław Śląski, Sieradz, Pa- } \\
\text { bianice, Świdnica }\end{array}$ \\
\hline 2 & $\begin{array}{l}\text { Społeczna Akademia Nauk } \\
\text { w Łodzi }\end{array}$ & 26 & + & + & + & + & $\begin{array}{l}\text { F: Warszawa; W: Kraków, Lon- } \\
\text { dyn; WZ: Bełchatów, Kielce, Ko- } \\
\text { łobrzeg, Ostrów Wlk., Sieradz, } \\
\text { Szczecinek, Świdnica, Tarno- } \\
\text { brzeg, Zduńska Wola; SAN w } \\
\text { Brodnicy, Garwolinie, Olkuszu }\end{array}$ \\
\hline 3 & $\begin{array}{l}\text { Szkoła Wyższa Ekonomii i Zarzą- } \\
\text { dzania w Łodzi }\end{array}$ & 5 & + & & & + & \\
\hline 4 & $\begin{array}{l}\text { Uczelnia Nauk Społecznych } \\
\text { w Łodzi }\end{array}$ & 4 & + & + & & + & \\
\hline 5 & $\begin{array}{l}\text { Wschód-Zachód Szkoła Wyższa } \\
\text { im. Henryka Jóźwiaka w Łodzi }\end{array}$ & 2 & + & & & + & WZ: Nowy Sącz \\
\hline 6 & $\begin{array}{l}\text { Wyższa Szkoła Biznesu } \\
\text { i Nauk o Zdrowiu w Łodzi }\end{array}$ & 3 & + & + & & + & F: Rybnik, Zielona Góra \\
\hline 7 & $\begin{array}{l}\text { Wyższa Szkoła COSINUS } \\
\text { w Łodzi }\end{array}$ & 1 & + & & & & \\
\hline 8 & $\begin{array}{l}\text { Wyższa Szkoła Edukacji Zdro- } \\
\text { wotnej i Nauk Społecznych w Ło- } \\
\text { dzi }\end{array}$ & 1 & + & + & & & \\
\hline 9 & $\begin{array}{l}\text { Wyższa Szkoła Finansów i Infor- } \\
\text { matyki im. prof. J. Chechliń- } \\
\text { skiego w Łodzi }\end{array}$ & 7 & + & & & + & W: Kalisz \\
\hline 10 & $\begin{array}{l}\text { Wyższa Szkoła Informatyki i } \\
\text { Umiejętności w Łodzi }\end{array}$ & 5 & + & + & & + & WZ: Bydgoszcz \\
\hline 11 & $\begin{array}{l}\text { Wyższa Szkoła Kosmetyki i Nauk } \\
\text { o Zdrowiu w Łodzi }\end{array}$ & 1 & + & + & & + & \\
\hline 12 & $\begin{array}{l}\text { Wyższa Szkoła Studiów Między- } \\
\text { narodowych w Łodzi }\end{array}$ & 7 & + & + & + & + & \\
\hline 13 & $\begin{array}{l}\text { Wyższa Szkoła Zawodowa Łódz- } \\
\text { kiej Korporacji Oświatowej w Ło- } \\
\text { dzi }\end{array}$ & 1 & + & & & + & \\
\hline
\end{tabular}




\begin{tabular}{|c|l|c|c|c|c|c|c|}
\hline 14 & $\begin{array}{l}\text { Wyższa Szkoła Biznesu i Przeds. } \\
\text { w Ostrowcu Św., WZ w Toma- } \\
\text { szowie Maz. }\end{array}$ & 3 & + & & & + & \\
\hline 15 & $\begin{array}{l}\text { Wyższa Szkoła Gospodarki Kra- } \\
\text { jowej w Kutnie }\end{array}$ & 9 & + & + & & + & \\
\hline 16 & $\begin{array}{l}\text { Wyższa Szkoła Handlowa w Ra- } \\
\text { domiu. Studia w Piotrkowie Try- } \\
\text { bunalskim }\end{array}$ & 30 & & & & + & \\
\hline
\end{tabular}

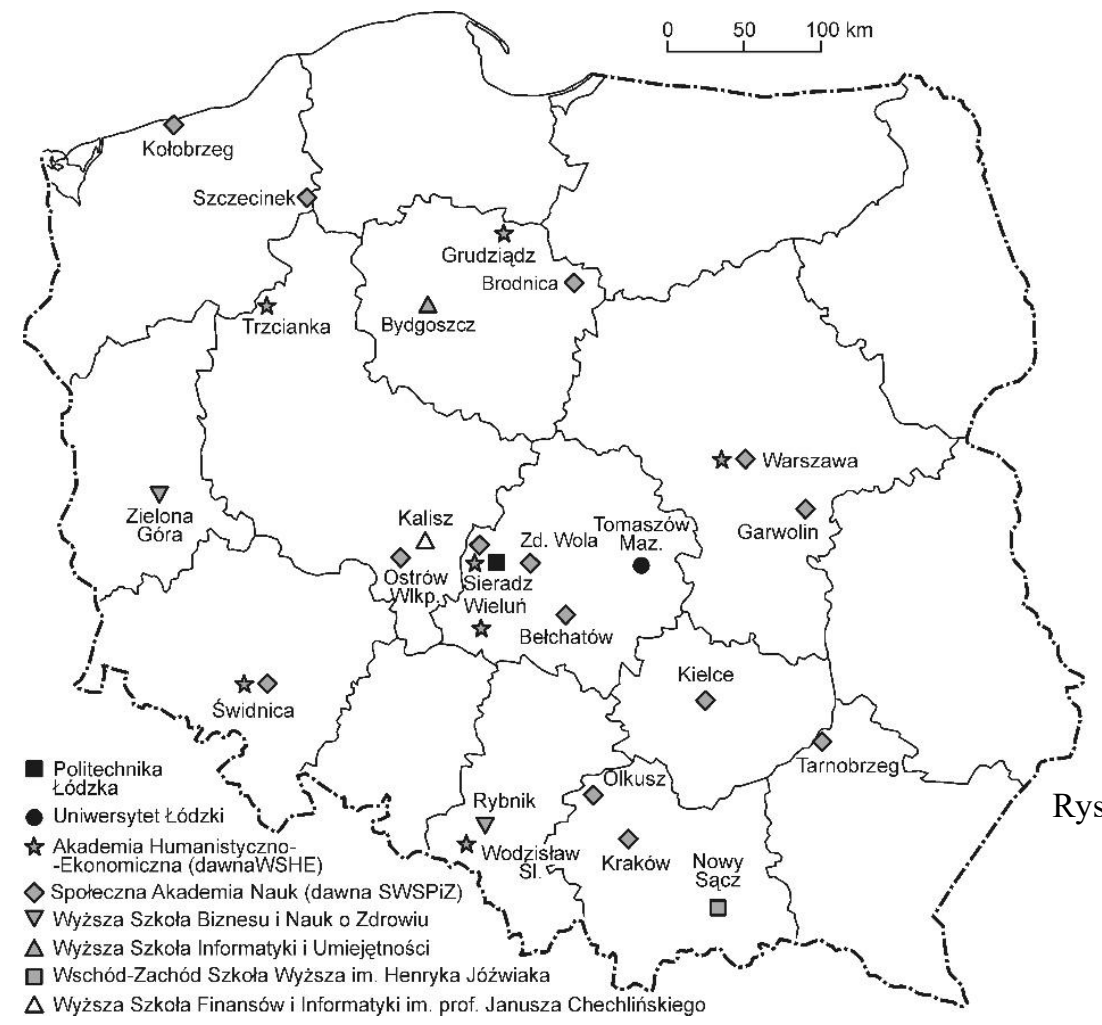

$\Delta$ Wyższa Szkoła Finansów i Informatyki im. prof. Janusza Chechlińskiego
Rys. 7. Zamiejscowe ośrodki dydaktyczne łódzkiego ośrodka akademickiego w r. ak. 2018/2019

Branches of Łódź universities in the academic year 2018/19

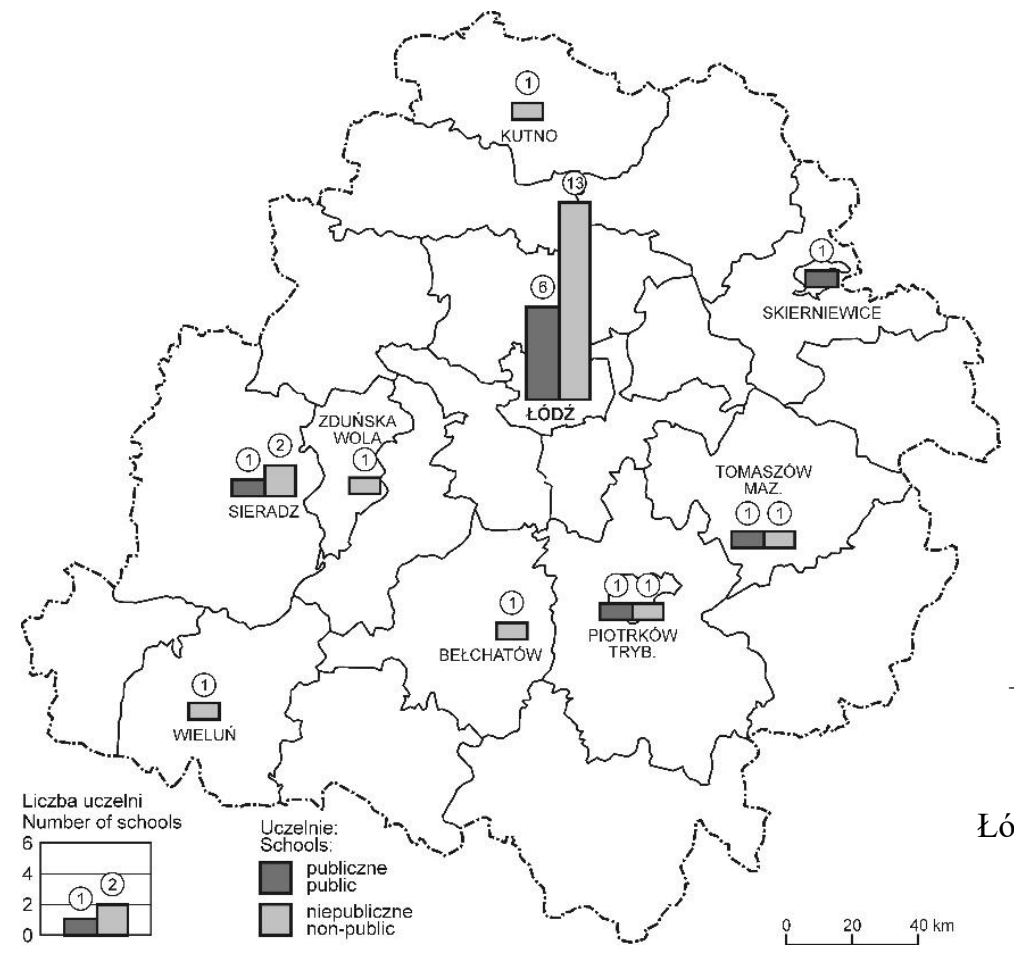

Rys. 8. Łódź i 8 miast powiatowych - siedzib wyższych uczelni i ośrodków zamiejscowych w woj. łódzkim w roku akademickim 2018/2019

Łódź City and eight poviat (district) centres - seats of universities and/or branches thereof in the academic year 2018/19 
Akademia Humanistyczno-Ekonomiczna, Społeczna Akademia Nauk i Wyższa Szkoła Studiów Międzynarodowych. Uprawnienia do prowadzenia studiów doktoranckich posiadają wyłącznie wymienione wyżej szkoły wyższe dysponujące odpowiednim potencjałem naukowym i zapleczem dydaktycznym

\section{Podsumowanie}

Szkolnictwo wyższe w województwie łódzkim rozwinęło się dopiero po II wojnie światowej i przez blisko pół wieku reprezentowane było wyłącznie przez szkoły publiczne $\mathrm{z}$ siedzibami w Łodzi. W ostatniej dekadzie XX w. dołączyły do nich liczne łódzkie szkoły niepubliczne oraz dalsze zamiejscowe ośrodki dydaktyczne, a także ośrodki zamiejscowe szkół państwowych. Dzięki temu, niektóre przemysłowe ośrodki miejskie województwa łódzkiego otrzymały nową funkcję - akademicką. Jednak nie zawsze ją utrzymały np. w Łowiczu, jednym z najstarszych miast omawianego województwa o średniowiecznej genezie szkolnictwa i lokalnej inteligencji, nie funkcjonuje już od kilku lat jedna $\mathrm{z}$ pierwszych uczelni niepublicznych - Mazowiecka Wyższa Szkoła Humanistyczno-Pedagogiczna. W roku jubileuszu 100-lecia województwa łódzkiego szkoły wyższe działały w 9 miastach, oczywiście najwięcej było ich w Łodzi. Pod względem liczby studentów województwo łódzkie zajmuje 6. miejsce w kraju, a 4. pod względem liczby studentów - obcokrajowców.

W związku z postępującym procesem wyludniania się województwa łódzkiego, należy spodziewać się, że szkoły wyższe, poza Łodzią utrzymają się tylko w miastach, które w latach 19751998 były siedzibami władz wojewódzkich - Sieradzu, Skierniewicach i Piotrkowie Trybunalskim, a w których funkcjonują uczelnie publiczne. Prawdopodobnie w Lodzi przetrwa jedynie kilka uczelni niepublicznych, w tym zapewne Akademia Humanistyczno-Ekonomiczna i Społeczna Akademia Nauk, szkoły o najszerszej ofercie dydaktycznej, dobrej współpracy z otoczeniem, ożywionej działalności kulturalnej, a także najlepszym wyposażeniu i nowoczesnych obiektach w centrum miasta.

Wyższe szkoły z siedzibami w Łodzi przyczyniają się nie tylko do rozwoju funkcji akademickiej miasta, lecz także oddziałują poza granice województwa dzięki swym wydziałom zamiejscowym, w 24 miastach 11 województw. Minione 74 lata funkcjonowania szkół wyższych w Łodzi zaowocowało powstaniem trzech kampusów akademickich: Politechniki Łódzkiej, Państwowej Wyższej Szkoły Filmowej Telewizyjnej i Teatralnej oraz wspólny Uniwersytetu Łódzkiego, Uniwersytetu Medycznego, Akademii Sztuk Pięknych i Akademii Humanistyczno-Ekonomicznej. Kampus PŁ położony jest w bezpośrednim sąsiedztwie południowo-zachodniej części Śródmieścia na terenach poprzemysłowych, które po rewitalizacji nabrały nowego charakteru, uzupełnione zostały nowoczesną architekturą z XXI w., ale odnowiony park z willami Józefa i Reinholda Richterów ciągle przypomina o dziewiętnastowiecznej świetności przemysłowej Łodzi. Kampus PWSFTviT usytuowany przy południowo-wschodniej granicy Śródmieścia obejmuje pałac Oskara Kona, nowoczesne kino, studia filmowe, a w jego sąsiedztwie $\mathrm{w}$ dawnym pałacu Karola Scheiblera, twórcy Łodzi przemysłowej, mieści się Muzeum Kinematografii. Vis-ávis tej uczelni rozciąga się jeden z najstarszych łódzkich parków. Największy jest trzeci kampus, UŁ, UM, ASP i AHE, rozciągający się poza północno-wschodnią częścią Śródmieścia. Poza zrewitalizowanymi obiektami poprzemysłowymi AHE znajdują się tam także nowoczesne, otoczone zielenią, budynki ASP, UM i UŁ.

Rola wyższych uczelni w organizacji przestrzeni zurbanizowanej Łodzi jest istotna z racji pełnienia funkcji akademickiej, a obiekty uczelniane pozytywnie wyróżniają się w skali miasta i Polski (np. gmach Wydziału Prawa i Administracji w kształcie paragrafu, zabudowa kompleksu ASP w barwach Katarzyny Kobro). W XIX i XX w. główną funkcją Łodzi był przemysł, który z sukcesem zastępuje obecnie funkcja akademicka. Mimo, że należy ona do młodszych funkcji wielkomiejskich, to bez wątpienia jest najbardziej czytelna w przestrzeni tego trzeciego co do wielkości miasta Polski. Dzięki PWSFTviT, (a także innych uczelni) Łódź przyjęto w 2017 r. do Sieci Miast Kreatywnych UNESCO jako Miasto Filmu.

\section{Literatura}

Bandurka M. 1987. Narodziny Łodzi akademickiej. Acta Universitatis Lodziensis, Folia Historica 30: 135-155.

Baranowski B., Kaczmarek R. 1952. Starania Łodzi o wyższą uczelnię. W: B. Baranowski, K. Duda-Dziewiarz (red.) Materialy do dziejów Uniwersytetu Łódzkiego (1945-1950). Wyd. UŁ, Łódź: 14-15. 
Baranowski K. 1977. Oddział Wolnej Wszechnicy Polskiej w Łodzi, 1928-1939. Warszawa-Łódź: 13-225.

Baranowski K. 1993. Początki Łodzi akademickiej. Szlakami Nauki 21, ŁTN, Łódź: 13-234.

eu.europa eu/Eurostat/statistics Tertiary_education_statistic YB2017, data wejścia 15.11.2018

Dylik J. 1971. Województwo ze stolicą bez antenatów. Szlakami Nauki 15, ŁTN, Łódź.

Jałmużna T. 1996. Z dziejów akademickiej Łodzi. Wyższa Szkoła Pedagogiczna 1946-1956. Wyd. UŁ, Łódź: 7-33.

Kiciński F. 1987. Materiały do dziejów wydziałów medycznych Uniwersytetu Łódzkiego i Akademii Medycznej w Łodzi w latach 1945-1955. Annales Academiae Medicae Lodziensis XXVIII: 64-123.

Kita J., Pytlas S. 1996. Uniwersytet Łódzki w latach 1945-1995. Wyd. UŁ, Łódź: 13-43.

Krubski K., Miller M., Turkowska Z., Wiśniewski W. ok. 1998. Filmówka. Powieść o łódzkiej szkole filmowej. Wyd. Tenten, Warszawa: 5-20.

Kwiatek J., Lijewski T. 1998. Leksykon miast polskich. Wyd. MUZA SA, Warszawa: 954-978.

Liszewski S., Szafrańska E., Wolaniuk A. 2008. Szkolnictwo wyższe Łodzi i jego rola w rozwoju funkcji metropolitalnej miasta. ŁTN, Łódź: 89-93.

Liszewski S., Szafrańska E., Wolaniuk A. 2012. Nauka łódzka na tle nauki w Polsce i w Europie. Konkurencyjność Łodzi jako ośrodka naukowego. ŁTN, Łódź: 12-22.

Przybylski R. (red.) 1995. Politechnika Łódzka 19451995. Ksiega Jubileuszowa. Nakładem Politechniki Łódzkiej, Łódź: 12-16.

Rocznik Statystyczny Miasta Łodzi. 1965. Miejski Urząd Statystyczny w Łodzi. XIV. Łódź: 346359.

Roczniki Statystyczne Województwa Łódzkiego. 1976, 1977, 1980, 1982, 1984, 1986, 1989, 1990,1992, 1994, 1996, 1998, 2000, 2002, 2004, 2006, 2008, 2010, 2012, 2014, 2016, 2018, Łódź, WUS.

Szkolnictwo wyższe w roku akademickim 2017/2018. 2018. GUS: 119.

Szkoły wyższe i ich finansowanie w 2016 r. Informacje i opracowania statystyczne. 2018. GUS, Warszawa: 45-46.

Wolaniuk A. 1997. Funkcje metropolitalne Łodzi i ich rola w organizacji przestrzeni. Szlakami Nauki 25, ŁTN, Łódź.

Wolaniuk A. 2001. Szkolnictwo wyższe i nauka. W: S. Liszewski (red.) Zarys monografii województwa łódzkiego. ŁTN, Łódź: 342-350.

Wolaniuk A. 2008. Szkolnictwo wyższe. W: J. Dzieciuchowicz (red.) Ustugi nierynkowe $w$ przestrzeni miejskiej Łodzi. Wyd. UŁ, Łódź: 86-107.

\section{Summary}

The beginnings of higher education in the Łódź Voivodeship go back to the 19th century. During the capitalist boom in the textile industry, there appeared the first attempts to establish a technical university in Łódź, which would prepare employees for the growing textile industry sector. After the fall of the January Uprising (1863) and the closing of the Agriculture and Forestry University Institute at Puławy, Łódź was chosen as the prospective seat of the technical university, but it was never established. Afraid of the power of Łódź industrialists, the Russian authorities prevented the founding of a university in Łódź, and factory owners, mostly of German and Jewish origin, educated their children in Western Europe and thus were not interested in establishing a university in Łódź. Before Tsar Nikolai II's visit to Łódź, the authorities of Łódź were granted permission to found a technical university, but in the end it was in Warsaw that it was opened.

Another attempt to create a Łódź Technical University in 1921 was also unsuccessful; the Sejm (Parliament) supported the proposal to open a university, but the Minister of Treasury opposed it and agreed to found the Warsaw Technical University instead. An attempt to turn the Teachers' Institute in Łódź (1921-1928) into a university also failed. Another attempt was the Higher School of Social and Economic Sciences, set up in 1924, but it was open for only 4 years, until the Łódź branch of the Warsaw Free Polish University was created in 1928.

Establishments functioning in Łódź during the interwar period, including the Teachers' Institute (which was not transformed into a university), the private Higher School of Social Sciences, and the Łódź branch of the Free Polish University, laid the foundation for establishing a university in its full right only after World War II. The long period of trying to establish a university in Łódź ended on 24th May 1945, with a decree instituting both the University of Łódź and the Łódź Technical University. 1945 was a year in which academic inaugurations were celebrated at eight higher schools: Łódź University, the Technical University, the State Music Conservatory, the State College of Fine Arts, the Higher School of Administration Sciences, the Teachers College, the University of Life Sciences and the Warsaw School of Economics. In 1946, they were followed by the State Theatre School and the State College of Pedagogy. In 1948 the Film College was established, which after two years was gran- 
ted university rights as the State Film School. After liberation, due to the huge war damages inflicted in Warsaw, Łódź became the seat of some additional higher schools and colleges for preparing administrative and political sector employees to work in a new political and economic system. Those institutions operated until the 1960s.

In 1961-1993, in Łódź, there were six state universities: Grażyna and Kiejstut Bacewicz Music Academy; Władysław Strzemiński Academy of Fine Arts; Leon Schiller State Higher School of Film, Television and Theatre; the Technical University of Łódź; the University of Łódź; and the Medical University. The return to a free market economy after 1989 started the process of creating many private universities in Poland - the first in Łódź was set up in 1993. In the academic year 1994/95, there were only three private universities in the whole voivodeship but their number was steadily growing, to reach 32 in the academic year 2009/10. The depopulation processes taking place in the voivodeship, financial problems and increasing costs of education led to many private schools gradually closing down. In the academic year 2018/19, apart from the abovementioned six public universities and the university branch at Tomaszów Mazowiecki, there were also the State College of Applied Sciences in Skierniewice, and the Jan Kochanowski Kielce University branch in Piotrków Trybunalski. The private sector contained 13 non-public universities in Łódź, and three schools outside the city (those at Kutno, Piotrków Trybunalski and Tomaszów Mazowiecki). Two non-public Łódź universities have their branches in four other cities of the Łódź Voivodeship, in the towns of Bełchatów, Sieradz, Wieluń and Zduńska Wola.

In the academic year 2018/19, universities based in Łódź had branches in 24 cities in 11 voivodeships across the country.

In 1945, nearly 10,000 students started their university studies in the Łódź Voivodeship and in the centrally planned economy period their number increased to 33,500 in the academic year 1976/77. During the period 1990-1999, the largest number of students $(142,500)$ was recorded in the academic year 2007/08. This record was followed by a considerable decrease in student numbers - to 85,200 in $2017 / 18$. In the first decade of the $21^{\text {st }}$ century, there were over 100,000 people studying in Łódź Voivodeship, including 30-46\% at private universities. Since 2010, when non-public schools started to close down, the share of students educated in this sector has fallen to about $20 \%$. The whole educational cycle comprising Bachelor's,
Master's, and $\mathrm{PhD}$ and Postgraduate studies is offered by the first six state universities (Music Academy, Academy of Fine Arts, Technical University, State Higher Film, Television and Theatre School, University of Łódź and Medical University), as well as by three private ones (AHE/The Academy of Humanities and Economics, SAN/Social Academy of Sciences and WSSM/International Studies Academy). The number of non-public universities within the Łódź Voivodeship is decreasing, but they run external education centres. Currently (in the academic year 2018/19), six private Łódź universities are running such centres in 24 cities or towns in 11 voivodeships.

The prestige of an academic centre is determined by the number of foreign students. This number has been systematically rising in the Łódź Voivodeship. In the academic year 2016/17, foreign students at the University of Łódź made up nearly $9 \%$ of the all foreign students at all the universities in Poland; those studying at the Technical University of Łódź comprised $8 \%$ of all the students at Polish technical universities, and foreign students at the Medical University made up $10.3 \%$ (compared to $10.7 \%$ at the Warsaw Medical University). At Łódź art universities, foreigners make up $22.7 \%$ of all the foreign students in Poland, including $7.3 \%$ studying at the State Higher School of Film, Television and Theatre. The faculty of film directing at the Łódź Film School is the most popular worldwide of all Polish universities.

Universities are major employers in the Łódź Voivodeship, and the number of academic teachers increased from several hundred in 1945 to 7,800 in the first decade of the 21 st century. After that, as a result of the closing down of private universities, the number of teachers fell to 6,300 in the academic year 2016/17.

The development of the academic function in Łódź after World War II positively contributed to the spatial structure of the city. Three student campuses were organised: the Technical University campus in the south-western section of Sródmieście (the central part of the city), spreading over a post-industrial area; the common campus University of Łódź, the Academy of Fine Arts campus and the University of Łódź; the Academy of Humanities and Economics campus in the north-eastern part of the city centre; and the Film School campus at the south-eastern border of Śródmieście.

State universities have not only built new, modern buildings, but have also contributed to the revitalisation of many old post-industrial buil- 
dings, industrialists' palaces and villas, while the State College of Applied Sciences at Skierniewice has been involved in the revitalisation of a post-military site. Private universities have converted and revitalised old tenement houses and post-industrial areas in the city centre.

Despite the fact that the academic function is one of the youngest metropolitan functions of Łódź City, and of the Łódź Voivodeship, too, it is among the best visible in the urban space of Łódź City and the town of Skierniewice. The role of Łódź universities in the organisation of the urban space is significant not only because they perform the academic function, but also due to the interesting architecture - revitalised $19^{\text {th }}$-century post- industrial archtecture (The Technical University and the Academy of Humanities and Exonomics), as well as modernist, glass buildings, erected in the $21^{\text {st }}$ century (the Technical University, University of Łódź, the Medical University). Student campuses are among the best-kept zones in the city and due to the adaptation of post-industrial areas and buildings, an air of the city's $19^{\text {th }}$-century grandeur has been restored. In the $19^{\text {th }}$ and $20^{\text {th }}$ century, Łódź's lead function was industry; now that is being successfully replaced and rooted out by academia. Łódź universities provide jobs and the students rejuvenate the central part of this unique city. 